\title{
ENVIRONMENTAL TOBACCO SMOKE (ETS) AND BEHAVIOR RISK ON PREGNANT WOMEN
}

\author{
Anita Dewi Moelyaningrum1
}

1Lecturer at Department of Environmental Health and Occupational Health and Safety, School of Public Health University of Jember.

Correspondence: FKM UNEJ Jl. Kalimantan I/ 93 Jember. Telp. 062 (0331) 337878, 322995.

Email: anitamoelyani@gmail.com or anitadm@unej.ac.id

\begin{abstract}
Backgrounds. Tobacco is one of the sources of indoor air pollutants. Smoking is hazardous not only for active smokers but also for passive smoker those who have to breathe involuntarily the environmental tobacco smoke (ETS)

Objectives. This research analyzes the knowledge, attitude, and behavior risk of pregnant women and environmental tobacco smoke (ETS)

Methods. This research was an observational analytical study conducted cross-sectionally among the pregnant women. The samples size ware taken for 45 pregnant women which come to paramedics in Sumber Sari area conducted April to may 2012. The characteristic were collected through interview guide.

Results.

The Respondent's Characteristics are in the range 23-35 years old $(68,8 \%)$, the number of parity is the first pregnant $(48,9 \%)$, the majority of education in elementary school $(31,1 \%)$, the majority of working status is housewived $(31,1 \%)$. The husband's respondent characteristics are in the range 23-35 years old, the majority of education is a senior high school $(28,9 \%)$, and working status is nongovernment officials $(88,9 \%)$.

The majority of knowledge is enough $(48,9 \%)$, neutral attitude about smoke harmful $(71,1 \%)$, and behavior risk is high $(86,7 \%)$, and the exposure risk of ETS is high $(48,9 \%)$.

There was a correlation $(p=0,01, \alpha=0,05)$ between behavior risk and exposure risk of ETS.

Conclusions. It concluded that there is behavior risk in pregnant women and exposure risk of ETS. To get the good quality generation in the future, Indonesia must build the policy in health system limiting exposure to ETS especially for pregnant women and fetus.
\end{abstract}

Keywords: behavior risk, pregnancy, ETS. 


\section{INTRODUCTION}

There is 1,26 Million smoker in the world. And more than 15 Million cigarettes inhaled people in the world. Indonesia is the developing country that had the much active smoker. According to World Health Organization (WHO), Indonesia is the third in the world and cause the death till 400, 000 people every year. There are 28,2 \% Indonesian are an active smoker, it means that there is one active smoker among four people (BPS, 2010).

Prevalence active smoker in East Java who smoking every day is 25,1\% (Riskesdas, 2010). Jember is a city in the east java Indonesia. East Java is the area which the highest production of tobacco in Indonesia with total production almost $56 \%$. Total production of tobacco in east Java in 2011 are 114816 ton (East java agricultural department of Indonesia, 2011).

Indoor air pollution among the top five environmental risks to public health in America. EPA (Environmental Protection Agency) studies of human exposure to air pollutants indicate that indoor levels of many pollutants often are significantly higher than outdoor levels. These levels of indoor air pollutants are of particular concern because it is estimated that most people spend approximately 90 percent of their time indoors. Indoor air pollutants can occur in the in homes, office, schools and other indoor environments where people live, work and play.

Tobacco is one of the sources of indoor air pollutants. Tobacco is the second major cause of death and disease in the world. One in ten deaths of adults worldwide occurs due to smoking which comprises about 5 million deaths every year. Cigarettes had a lot of poison that can intake the body while smoke. Smoking is hazardous not only for active smokers but also for passive smoker those who have to breathe involuntarily the environmental tobacco smoke (ETS). Secondhand tobacco smoke or called (ETS), is a combination of mainly sidestream smoke released from the burning end of a cigarette and also from a partly exhaled mainstream smoke. Toxic gases and particulate matters of ETS remain suspended in the air of a room, attached to the surface of furniture and walls long after smoking is has ceased (WHO, 2007).

ETS is very dangerous because it contains mere than 4000 toxic chemical and approximately 69 "known" inducer carcinogens (WHO: 2007 EPA:1992). It has been shown that sidestream ETS smoke actually contains higher concentrations of certain toxic chemicals, including several cancer-causing ones, than does mainstream smoke. Some compounds are 10 times higher in sidestream than in mainstream smoke. The passive smokers get nicotine 
and tart $3 \mathrm{x}$ more than an active smoker, 5x carbon oxide (CO), 46x ammonia, 3x nickel, and 50x Nitrosamine (EPA 1992; CDC 2004, 2006).

The toxic substances of ETS are nicotine, carbon monoxide, nitrogen oxide, ammonia, acrolein, methyl isocyanate, hydrogen cyanide, phenol, cadmium, tart, arsenic, formaldehyde, acetone, respirable suspended particulates, etc. The carcinogens in ETS are benzopyrene (lung cancer), nitrosamines (cancers of the bladder, respiratory system, and other organs), aromatic amines (cancers of the bladder, and breast), benzene (leukemia), formaldehyde (nasal cancer) and polonium-210 (radioactive).

In adults ETS is a human lung carcinogen, can cause lung cancer in adult nonsmokers and that children of parents who smoke have increased frequency of respiratory symptoms and lower respiratory tract infections, and heart disease. And in a children ETS exposure increases the risk of lower respiratory tract infections such as bronchitis and pneumonia. EHSO (2011) estimates that between 150,000 and 300,000 of these cases annually in infants and young children up to 18 months of age are attributable to exposure to ETS. Of these, between 7,500 and 15,000 will result in hospitalization, increases the prevalence of fluid in the middle ear, a sign of chronic middle ear disease, irritates the upper respiratory tract and is associated with a small but significant reduction in lung function, increases the frequency of episodes and severity of symptoms in asthmatic children. The report estimates that 200,000 to $1,000,000$ asthmatic children have their condition worsened by exposure to environmental tobacco smoke.

Pregnancy is the special condition from mother which there is fetus development their system organ almost 9 month. Mother must be careful to take care the fetus from the environment poison exposure such as cigarette smoke. Smoking during pregnancy is associated with increased risk of maternal and infant adverse outcomes. For the mother, these include higher rates of placental abruption, placenta praevia, premature labor and premature rupture of membranes. For the baby, adverse outcomes include low birth weight, preterm birth, intra-uterine growth retardation, perinatal death and Sudden Infant Death Syndrome (CDC, 2004; 2006). The agreement state by Ridwan (2006) says that smoke ETS have the risk of placental abruption and low birth weight ( $\operatorname{sig} 0,01$ ), it depends on the number of husband cigarettes smoked per day. There is a scientific evidence that maternal ETS exposure during pregnancy may lead to transplacental carcinogenesis (CDC, 2004). An association between passive smoking of pregnant women and postnatal childhood cancers, such as leukemia, lymphoma, and brain tumor has been also found (CDC, 2004). 
The mother`s knowledge, attitudes and behavior to take care the pregnancy is the most important thing. It can decrease the exposure risk toxicant during the pregnancy. The aims of the research are analysis the correlation between knowledge, attitude and behavior risk of pregnant women and environmental tobacco smoke (ETS).

\section{METHODS AND MATERIALS}

This research was an observational analytical study conducted cross-sectionally among the pregnant women. The samples size ware taken for 45 pregnant women which come to paramedics in Sumber Sari, Jember district area, Indonesia that conducted April to May 2012. The characteristic were collected through interview guide.

\section{RESULTS AND DISCUSSION}

\section{Respondent Characteristics}

Age. The average of age of the participants are 23-35 years old $(68,8 \%)$. Age is important thing in the maturity. It's influenced in the knowledge and attitude. People which are $23-35$ years old called young adult (Santrock, 2001). The optimum development of physic and mental occurs in the young adult. This is the best age for a woman to get pregnant because in this age women were predicted in the best physic and mental to get pregnancy.

Parity. There are 48,9\% respondents that get the first pregnancy and 31,1\% get the second pregnancy (see table 2). The history of pregnancy is the important thing for a mother to take care the baby. The mother who gets the first pregnancy usually always more carefully than others, that because they don't have experience about how to take care the pregnancy.

Education. The majority education of the Respondents $(31,1 \%)$ is an elementary school, and college is $13,3 \%$. Education contributes to the knowledge, attitude, and practice (Sumitro, 1998). A good education can help people more open to any others and access information.

Working Status. Most of the respondents are housewife $(31,1 \%)$, non-officer (farmer, personal selling etc) is $28,9 \%$ and the officer (teacher, nurse, government officer) is $26,7 \%$. Approximately housewives have much time at home than working women. They spend a lot of time at home while the pregnancies. So if the family members are an active smoker, ETS at home will be higher around them. (see table 1) 
Table 1. Distribution Age of the Respondents

\begin{tabular}{|c|c|c|c|}
\hline No & $\begin{array}{c}\text { Respondent } \\
\text { Characteristic }\end{array}$ & Amount & $\%$ \\
\hline \multirow[t]{6}{*}{1.} & $\begin{array}{l}\text { Age range of } \\
\text { respondent (years) }\end{array}$ & & \\
\hline & $15-18$ & 4 & 8,8 \\
\hline & $19-22$ & 9 & 20 \\
\hline & $23-35$ & 31 & 68,8 \\
\hline & $>35$ & 1 & 2,2 \\
\hline & Total & 45 & 100 \\
\hline \multirow[t]{6}{*}{2} & Number of parity & & \\
\hline & 1 & 22 & 48,9 \\
\hline & 2 & 14 & 31,1 \\
\hline & 3 & 7 & 15,6 \\
\hline & 4 & 2 & 4,4 \\
\hline & Total & 45 & 100 \\
\hline \multirow[t]{6}{*}{3.} & Education & & \\
\hline & Elementary school & 14 & 31,1 \\
\hline & Junior high school & 13 & 28,9 \\
\hline & Senior high school & 13 & 28,9 \\
\hline & College & 5 & 13,3 \\
\hline & Total & 45 & 100 \\
\hline \multirow[t]{5}{*}{4.} & Working Status & & \\
\hline & Housewive & 14 & 31,1 \\
\hline & $\begin{array}{l}\text { Non officer (farmer, } \\
\text { personal selling etc) }\end{array}$ & 13 & 28,9 \\
\hline & $\begin{array}{l}\text { Officer (teacher, } \\
\text { nurse, goverment } \\
\text { officer etc) }\end{array}$ & 12 & 26,7 \\
\hline & Total & 45 & 100 \\
\hline
\end{tabular}

\section{HUSBAND`S RESPONDENT CHARACTERISTIC}

Age. The majority of husband's respondent's age is $23-25$ years old $(86,6 \%)$ and there are $13,4 \%$ was $>35$ years old. Education. The majority of husband`s respondent's education is a senior high school $(28,9 \%)$. Working Status. Non-government officially like a farmer, gardener, street vendors, etc are the majority $(88,9 \%)$. (see table 2 ) 
Table 2. Distribution Age of the Husband`s Respondent

\begin{tabular}{|c|c|c|c|}
\hline No & $\begin{array}{c}\text { Husband's } \\
\text { Respondent } \\
\text { Characteristics }\end{array}$ & Amount & $\%$ \\
\hline \multirow[t]{6}{*}{1.} & $\begin{array}{l}\text { Age range of } \\
\text { husbands (years) }\end{array}$ & & \\
\hline & $15-18$ & - & - \\
\hline & $19-22$ & - & - \\
\hline & $23-35$ & 39 & 86,6 \\
\hline & $>35$ & 6 & 13,4 \\
\hline & Total & 45 & 100 \\
\hline \multirow[t]{6}{*}{2.} & Education & & \\
\hline & Elementary school & 12 & 26,7 \\
\hline & Junior high school & 11 & 24,4 \\
\hline & Senior high school & 13 & 28,9 \\
\hline & college & 9 & 20 \\
\hline & Total & 45 & 100 \\
\hline \multirow[t]{4}{*}{3.} & Working status & & \\
\hline & $\begin{array}{l}\text { Non-government } \\
\text { officially }\end{array}$ & 40 & 88,9 \\
\hline & $\begin{array}{l}\text { Goverment official } \\
\text { (teacher, nurse etc) }\end{array}$ & 5 & 11,1 \\
\hline & Total & 45 & 100 \\
\hline
\end{tabular}

\section{Knowledge of ETS Health Effects for Pregnant Women and Fetus}

Respondents` knowledge of cigarettes smoke is harmful during pregnancy was enough $(48,9 \%)$ because the majority incorrect indicated that smoking increase the risk of teratogen and risk of low birth weight. In other side, respondents` knowledge was high. There are $44,4 \%$ respondents understand health effect, particularly on pregnant woman and fetus. (see table 3)

Knowledge often comes from experience or other people like teachers, parents or media like television, newsletter, magazine etc (Tjitarsa, 1992). People will have behavior base on knowledge (Walgito, 2004). But not all researchers agree with it. Pona (1998) says that behavior does not always base on knowledge, a good knowledge of the healthy not always make people have the healthy behavior. In their research Passey (2012) show that knowledge of risk cigarettes smoke was high, but respondent still smoking during pregnancy because of the social norm (Passey, 2012) 
Table 3. Knowledge on ETS Health Effects for Pregnant Women and Fetus

\begin{tabular}{|cccc|}
\hline No & Knowledge & Amount & $\%$ \\
\hline 1. & less & 3 & 6,7 \\
2. & enough & 22 & 48,9 \\
3. & high & 20 & 44,4 \\
& Total & 45 & 100 \\
\hline
\end{tabular}

\section{Attitude Towards Smoking and ETS}

The majority of respondents had neutral attitudes $(71,1 \%)$ to cigarettes harmful during the pregnancy. (see Table 4) They agreed with the statement that not always stay away from cigarettes smoke during the pregnancy and inhaled cigarettes smoke at home. Their attitude was permissive toward to smoker and inhaled the cigarette smoke during pregnancy. The reasons why they had the attitude are smoking is the common habits. They consider that not commonly to forbidden the smoker smoking around them. Especially forbidden their husband, parents, brother, uncle, cousin or another member of their family to not smoking around them while during the pregnancy. There is correlation between knowledge and attitude (Purwanto, 98), good knowledge will produce good attitude (Notoatmojo, 2005). And a good attitude will produce good behavior (Gerungan, 2000).

Spearman SPSS 19 is used to analyze the correlation between knowledge and attitude in this research. Spearman correlation shows that there is no correlation between knowledge and attitude ( $p=0,07 ; \alpha=0,05)$. There are so many things influence the attitude. It can be of knowledge, belief, emotional, social norm, habits, etc. The fact shows that the respondents had enough knowledge about harmful of cigarette smoke during the pregnancy, but they had the netral attitude. Respondents considered that smoking at home while there is pregnancy is a normal social norm. Although they know the harmful of cigarette smoke, they couldn't do anything to avoid the smoke at home or another place.

The majority of respondents had bad behavior $(86,7 \%$ ) (see table 5). Respondents are highly exposed to environmental tobacco smoke (ETS) everywhere. They don't try to avoid the cigarette smoke during the pregnancy although at home. The early study (Atabekyan, 2007) shows this in forms tolerate the behavior of pregnant women towards passive smoking in the households and all interviewer mention no action to avoid or minimize tobacco smoke. They let their husband, parents, uncle, cousin and other people smoking at their home during the pregnancy. They say that they afraid to forbid other people who smoke around them. So they still inhaled the cigarette smoke during the pregnancy every time and everywhere. There 
is the correlation between attitude and behavior ( $\operatorname{sig} p=0,01 \alpha=0,05$ ). The neutral attitude of cigarette smoke contributes to the bad behavior of cigarette smoke. The determinants of this problem do not work separately, there are interrelated with each other as well as with social and cultural issues (Atabekyan, 2007)

Peer behavior (subjective norm) and attitude is an important thing influence the behavior. In the research Ganley (2012) had shown that Subjective norm and attitude may predict smoking but knowledge was not a predictor, whereas knowledge of the hazard of smoking does not appear to influence smoking behavior, but tobacco use among young adults may directly influence my overall attitude and peer and family smoking behavior.

This was agreed with the finding of an earlier study (Atabekyan, 2007) that 95\% women interviewed were exposed to ETS during their pregnancies. No rules to smoking at home, it shows that $53 \%$ reported that no restriction in households for family members and guest, smoking allowed in some rooms.

Table 4. Attitude Towards Smoking and ETS

\begin{tabular}{|llcc|}
\hline No & Attitudes & Amount & \% \\
\hline 1. & Negatif & 7 & 15,6 \\
2. & Neutral & 32 & 71,1 \\
3. & Positif & 6 & 13,3 \\
& Total & $\mathbf{4 5}$ & $\mathbf{1 0 0}$ \\
\hline
\end{tabular}

Table 5. Behavior Risk of Pregnant Women to Avoid ETS

\begin{tabular}{|llcc|}
\hline No & Behavior & Amount & $\%$ \\
\hline 1. & High & 39 & 86,7 \\
2. & Low & 6 & 13,3 \\
& Total & $\mathbf{4 5}$ & $\mathbf{1 0 0}$ \\
\hline
\end{tabular}

\section{EXPOSURE RISK OF ENVIRONMENTAL TOBACCO SMOKE}

According to smoking status of respondents, smoking status of husbands respondent, number of smoked cigarettes per day by family members, number of the smoker at home and Inhaled cigarette smoke at home during pregnancy. The exposure risk of Environmental Tobacco Smoke is high $(48,9 \%)$ and middle $(37,8 \%)$. See table 6 
The majority of the respondents are passive smokers (97,8\%). Respondent still inhaled the cigarette smoke during pregnancy at home because of there are people who active smoker at their home $(86,7 \%)$. The active smoker is husband, father, brother or cousin. There are more than one persons who are an active smoker at home (97,8\%), and they spend more than 12 cigarettes per day (48.9\%). Respondents claim to be inhaled the smoke of cigarettes at home during pregnancies $(91,1 \%)$

Table 6. The Exposure Risk of ETS at Indoor

\begin{tabular}{|llcc|}
\hline No & Attitude & Amount & $\%$ \\
\hline 1. & Low & 6 & 13,3 \\
\hline 2. & Middle & 17 & 37,8 \\
\hline 3. & High & 22 & 48,9 \\
\hline & Total & $\mathbf{4 5}$ & $\mathbf{1 0 0}$ \\
\hline
\end{tabular}

The analysis shows that there is a correlation between behavior ETS and exposure risk ( $\operatorname{sig} \mathrm{p}=0,01 \alpha=0,05$ ). The ETS behavior and exposure risk during pregnancies must be controlled because it can be dangered for mother and fetus. In their research (Carmen, et al, 2011) showed that baby from the active smoker mother and passive smoker had slow response, and baby which come from passive smoker mother (ETS) had low motoric development, and cannot control their behavior and responds well to their histologic, sensory, motoric and response.

\section{CONCLUSIONS AND RECOMMENDATION}

This study not only has identified knowledge, attitudes and risk behavior the pregnant women in the cigarettes smoke but also the risk exposure of cigarettes smoke at indoor. Respondents had a high exposure risk of ETS because of the social norm. They don't have a brave to forbidden the family member especially their husband not to smoke around them during their pregnancies. The government must be educated the members of family`s pregnant women not to smoking around the pregnant women and support the pregnant women to have a brave to avoid and leave the smoker to protect their pregnancy while the smoker is their husband, father or other people.

Stay away from the cigarette smoke during the pregnancy can produce a good quality generation in the future. Socialization about the harmful of cigarette smoke can be an application in the poster, leaflet, posyandu etc. Good cultural and social norm of cigarette 
smoking must be build together by government and community`s programs. To protect future generations of Indonesia a policy limiting exposure to ETS should be developed. Indonesia needs rule and health programs which designed to straighten up smoking area for people to create the good habits of behavior active smoker.

\section{REFERENCE}

1. BPS (2010). Badan Pusat Statistik Indonesa. www.bps.go.id

2. Riskesdas (2010). Laporan Nasional Riset Kesehatan Daasar (RISKESDS) Tahun 2010. . http. www.ppid.depkes.go.id (citatio on march 2012)

3. Laporan Kementrian Pertanian Republik Indonesia, 2011. Produksi Tanaman Tembakau di Indonesia. www.deptan.go.id (citatio on march 2012)

4. WHO (2007). Protection from exposure to second-hand tobacco smoke. Policy recommendations. 2007. Geneva, World Health Organization, 2007. www.who.int. (citation on 1 March 2012)

5. WHO (2007). Tobacco Free Initiative. Geneva, World Health Organization. www.who.int/entity/tobacco. (citation on 1 March 2012)

6. WHO (2007). Gender and tobacco control: A policy brief - 2007. World Health Organization. www.who.int/tobacco/.../policy brief.pdf. (citation on 1 March 2012)

7. Environmental Protection Agenc (1992). Respiratory health effects of passive smoking: Lung cancer and other disorders. Washington D.C.: Office of Health and Environmental Assessment, US Environmental. www.epa.gov. (citation on 1 March 2012)

8. EHSO (2011). Respiratory Health Effects of Passive Smoking. An EPA Fact Sheet; Reprinted by EHSO. http://www.ehso.com/SmokingRespHealth.htm. (citation on 1 March 2012)

9. CDC (2004). Centers for Disease Control and Prevention, National Center for Chronic Disease Prevention and Health Promotion, Office on Smoking and Health. The Health Consequences of Smoking: A Report of the US Surgeon General. Washington, DC: US Department of Health and Human Services; 2004. Available at: www.surgeongeneral.gov/library/smokingconsequences. Accessed on September 1, 2009. (citation on 1 March 2012)

10. CDC (2006). A Report of the Surgeon General. The health consequences of involuntary exposure to tobacco smoke. Atlanta, U.S. Dept of Health and Human Services, CDC, Office on Smoking and Health. www.surgeongeneral.gov. (citation on 5 March 2012) 
11. Ridwan (2006). Pengaruh Perilaku Merokok, Paparan asap rokok dan Kadar Nikotin terhadap Kejadian Bayi Berat Lahir Rendah. Konas JeEN. Semarang. 2007.

12. Santrock, J.W. (2001). Adolescence (8th ed.). North America: McGraw-Hill

13. Sumitro (1998). Pengantar IImu Pendidikan. Fakultas IImu Pendidikan Universitas Negeri Yogyakarta.

14. Tjitarsa, I.B. 1992. Pendidikan Kesahatan Pedoman Pelayanan Kesehatan.

15. Walgito, B. 2004. Pengantar Psikologi Umum. Yogyakarta: Andi.

16. Pona, La. 1998. Pekerja Seks Jalanan Potensi Penularan Penyakit Sexual. Yogyakarta: Kerjasama PPK-UGM dan The Ford Fondation.

17. Passey ME , Catherine A D'Este and Robert W Sanson-Fisher , 2012. The Knowledge, attitudes and other factors associated with assessment of tobacco smoking among pregnant Aboriginal women by health care providers: a cross-sectional survey. BMC Public Health. http://www.biomedcentral.com. (citation on 1 March 2012)

18. Purwanto H (1998). Pengantar Perilaku Manusia. Jakarta: EGC

19. Notoatmodjo, Soekidjo. 2003. Pendidikan dan perilaku kesehatan. Jakarta : Rineka Cipta.

20. Gerungan (2000). Psikologi Sosial. Bandung: PT. Refika Aditama.

21. Atabekyan L (2007), Knowledge, attitude, and practices of pregnant women regarding environmental tobacco smoke in Yerevan and Nor-Hachn, Armenia 2007: a Qualitative study. Complete Thesis. http://www.chsr.aua.am/mph2007.php. (citation on 2 March 2012)

22. Ganley BJ, dianne I Rosario (2012). The smoking attitude, Knowledge, intent, and behavior of adolescents and young adults : Implication for nursing practice. Journal of Nursing Education and Practice. ISSN 19254040 (print) ISSN 19254059 (online). Publish january $1, \quad 2013 . \quad$ DOI. 105430/jnep.v3n1p40. www.sciedu.ca/journal/index.php/jnep/article/download/1157/893. (citation on 1 March 2012)

23. Carmen H -Martínez, Victoria Arija Val, Joaquín Escribano Subías, Josefa Canals Sans. 2011. A longitudinal study on the effects of maternal smoking and secondhand smoke exposure during pregnancy on neonatal neurobehavior. Early Human Development, 2012; 88 (6): 403 DOI: 10.1016/j.earlhumdev.2011.10.004. (citation on 1 March 2012). 